Fikrah: Jurnal Ilmu Aqidah dan Studi Keagamaan

ISSN 2354-6147 EISSN 2476-9649

Tersedia online di: journal.stainkudus.ac.id/index.php/fikrah

DOI: $10.21043 /$ fikrah.v5i2.2722

\title{
Hubungan Antara Tuhan, Manusia dan Alam dalam al-Quran: Aplikasi Semantik Toshihiko Izutsu
}

\author{
Ahmad Sahidah \\ Universitas Utara Malaysia \\ ahmads@uum.edu.my
}

\begin{abstract}
Abstrak
Artikel ini ingin mengurai hubungan antara Tuhan, manusia, dan alam dalam al-Quran dalam pandangan Toshihiko Izutsu. Dengan menggunakan analisis semantik, sarjana Jepang ini memanfaatkan kaidah analitik untuk membiarkan al-Quran mentafsirkan konsepnya sendiri dan berbicara untuk dirinya sendiri. Untuk itu, penggunaan syair Arab untuk memahami arti dasar dari sebuah kata penting dan pada gilirannya makna relasional perlu dihadirkan dengan mengenal medan semantik dari lema yang diteliti. Dari sudut hermeneutik, pemikiran Izutsu memperlihatkan kesamaan dengan penafsiran sarjana Muslim tentang tema yang dimaksud. Dengan melihat hubungan Tuhan dan manusia dalam empat kerangka, ontologi, tuan-hamba, etik, dan komunikatif, Izutsu menegaskan bahwa kitab suci al-Quran tidak hanya bersifat etik tetapi juga praktik.
\end{abstract}

Kata kunci: Alam, al-Quran, manusia, semantik, Tuhan 


\begin{abstract}
This article explores the relationship between God, man, and nature in the Quran in Toshihiko Izutsu's view. Using semantic analysis, this Japanese scholar used the analytic principle to get the Quran interprets its own concepts and speaks for itself. For that reason, the use of Arabic poetry to understand the basic meaning of an important word and in turn, the relational meaning needs to be presented by knowing the semantic field of the researched dilemma. From a hermeneutic point of view, Izutsu's thought shows parallels with the Muslim scholar's interpretation of the theme. By looking at the relationship between God and man in the four skeletons, ontologies, masters, ethics, and communicative, Izutsu asserts that the holy book of the Quran is not only ethical but also practice.
\end{abstract}

Keywords: God, man, nature, semantics, Quran

\title{
Pendahuluan
}

Toshihiko Izutsu menegaskan bahwa al-Quran bisa dipahami melalui pelbagai sudut pandang yang berbeda, seperti teologi, filsafat, sosiologi, tata bahasa dan takwil (exegesis) (Esak, 1997, hal. 14). Ketika diusulkan sebuah pendekatan semantik di dalam mengkaji al-Quran, ini berarti bahwa ada hubungan erat antara metodologi semantik dengan pemahaman terhadap al-Quran dan sumbangannya bagi pengembangan pemikiran Islam secara umum. Izutsu (2004, hal. xii) juga mempertimbangkan pemikiran dari para sarjana sebelumnya atas analisis semantiknya, baik kalangan insaider maupun outsaider, seperti Stephen Ullmann, Leo Weisgerber, Paul Henle, Hamilton A. R. Gibb, Montgomery Watt, C. C. Torrey, Theodor Nöldeke, Ignác Goldziher, Lord Russell, Ferdinand de Saussure, Émile Durkheim, Alfred Giullame, Werner Caskel, Benjamin Whorf dan Karl Jaspers, Abu Hamid Muhammad al-Ghazali, yang juga dikemukakan sebagai gambaran teknik semantik modern (Izutsu, 2004, hal. 71), al-Juwaini, Ibnu Khaldun, Ibn 'Arabi, Ahmad Amin, Dawud Rahbar, dan alKirmani. Kenyataan ini sejalan dengan apa yang diungkapkan oleh Karl Mannheim, ahli sosiologi pengetahuan Jerman, bahwa:

Strictly speaking it is incorrect to say that the single individual thinks. Rather it is more correct to insist that he participates in thinking further what other men have thought before him. He finds himself in an inherited situation with patterns of thought which are appropriate to this situation and attempts to elaborate further the inherited modes of response or to substitute others for them in order to deal more adequately with the new challenges which have 
arisen out of the shifts and changes in his situation. Every individual is therefore in a two fold sense predetermined by the fact of growing up in a society: on the one hand he finds a ready-made situation and on the other hand he finds in that situation preformed patterns of thought and of conduct (Mannheim, 1936, hal. 3).

Dialektika pemikiran Izutsu banyak diilhami oleh pemikir sebelumnya, sehingga tidak mengherankan ketika terdapat gagasan yang sama maupun menyerupai, gagasan tentang bahwa al-Quran mempunyai konsepsinya sendiri yang dapat dipahami melalui perbandingan dengan weltanschauung ahli filsafat Barat Modern, Karl Jaspers (1970, hal. 3). Sarjana Jerman ini telah mengangkat masalah sifat simbolik dunia sebagai salah satu dasar dari sistem pemikirannya. Menurut penulis buku Philosophy, seseorang hidup pada beberapa tingkatan yang berbeda. Apabila manusia meninggalkan tingkatan normal sehari-hari, maka akal sehat (verstand), di mana benda-benda alam termasuk manusia tampak di hadapan mata, hanyalah sebagai benda-benda. Namun, jika melangkah ke dalam medan existenz, maka akan menemukan diri sendiri tiba-tiba berada di dunia asing, berdiri di hadapan Tuhan, yang secara filsafat disebut das Umgreifende, yaitu sesuatu yang sangat besar yang mencakupi semuanya, yang berasal dari Tuhan dan selalunya berbicara kepada kita, tidak secara langsung, tetapi melalui fenomena alam (Izutsu, 2004, hal. 144).

Ilustrasi tersebut menggambarkan bahwa pemahaman terhadap kitab suci tidak saja berhubungan dengan kemampuan kognitif tetapi juga wilayah intuitif dari seseorang pengkaji. Di sini, sekaligus syarat tersebut menunjukkan sebuah bukti bahwa kriteria pengkaji tidak hanya berkaitan dengan kepakaran tetapi juga perilaku dan kesusungguhannya untuk menangkap makna di balik teks, seperti para mayoritas penafsir tradisional.

\section{Metode}

Kajian ini menggunakan metode kualitatif yang mencoba untuk menarasikan pemikiran Toshihiko dengan menjadikan penelitian sebagai instrumen kunci, sehingga kajian ini lebih bersifat kepustakaan (Library Research) yang mengkaji gagasan (Moleong, 1989). Oleh sebab itu, objek kajian bersifat literatur yang meneliti sumber asli dari objek yang diteliti sebagai data yang dapat berbentuk karya yang mempunyai 
relevansi terkait dengan tema yang sedang dikaji (Sugiyono, 2005). Kajian ini menggunakan analisis data secara induktif, mengingat kajian yang dilakukan berbentuk kualitatif yang menafsirkan dari sejumlah yang bersifat khusus untuk ditarik pada simpulan yang bersifat umum (Anwar, 1998).

\section{Semantik dan Teks al-Quran}

Semantik adalah satu bidang kajian linguistik memiliki objek luas dan selalu mengalami perkembangan. Kata ini berasal dari bahasa Yunani semantikos, yang berarti memberi makna, arti, gejala, dan berasal dari kata sema yang mempunyai arti tanda. Sebagaimana dicatat oleh Stephen Ullmann (1972) dalam karya berjudul Semantics - An Introduction to the Science of Meaning bahwa dua cabang utama dari linguistik berkaitan dengan kata adalah etimologi yaitu kajian tentang asal-usul kata, dan kajian terhadap makna kata atau disebut semantik. Disiplin yang pertama adalah kajian kuno sementara yang terakhir adalah baru. Spekulasi tentang asal usul kata adalah sesuatu yang menonjol dibahas di dalam filsafat Yunani awal. Kita akan menemukan dua mazhab pemikiran yang saling bersaing yaitu naturalis yang mempercayai bahwa ada sebuah hubungan internal antara suara (sound) dan arti (sense). Sementara konvensionalis menegaskan bahwa hubungan ini secara murni bersifat sewenangwenang (arbitrer), yang juga dianut oleh banyak ahli linguistik terkini.

Dalam perkembangan awal, kajian semantik hanya terbatas pada makna teks. Namun pada perkembangan selanjutnya, kajian semantik mulai merambah pada wilayah bahasa dan pemikiran manusia. Dalam hal ini, tidak hanya dipahami sebatas media untuk mengungkapkan pemikiran manusia, tetapi bagian dari keterpengaruhan dari horison seseorang, dimana bahasa mempengaruhi ungkapan, pemikiran dan mengarahkannya pada sesuatu yang spesifik, hal ini disebut dengan 'medan semantik' (semantics field). Penjelasan yang terakhir ini mendapatkan kritik dari tulisan-tulisan Benjamin Lee Whorf yang konsen dalam kajian tata bahasa dibandingkan kosa kata (Ullman, 1972).

Izutsu menggunakan sejarah semantik sebagai alat analisa atas istilah-istilah kunci pada bahasa dengan beberapa aspek terkait, sehingga semantik menjadi kajian konseptual weltanschauung atau dasar masyarakat dalam menggunakan bahasa. Dengan 
demikian, semantik tidak hanya sebagai alat berbicara atau berpikir, tetapi menjadi dasar konseptual dan interpretasi atas fenomena yang melingkupi. Dalam hal ini, semantik sejenis weltanschauungslehre, yaitu sebuah kajian terhadap hakikat dan struktur kebudayaan dari peradaan dunia yang hidup dalam masyarakat tertentu sebagai paradigma keilmuan dengan menggunakan analisa metodologis atas konsepkonsep budaya yang lahir dari rahim peradaban masyarakat dan menyatu dalam ungkapan bahasa (Izutsu, 2004, hal. 3). Dengan bahasa yang sederhana, bahwa semantik al-Quran seharusnya dipahami hanya di dalam pengertian weltanschauung atau pandangan dunia al-Quran atau dengan kata lain visi al-Quran tentang alam semesta (universe). Kenyataan ini mengetengahkan sebuah tesis bahwa Islam berbeda dengan kepercayaan-kepercayaan dan agama-agama yang ada sebelumnya.

Semantik sebagai jenis ontologi yang konkrit, hidup dan dinamik, bukan semacam ontologi sistematik statik yang ditampilkan oleh seorang ahli filsafat pada tingkat pemikiran yang abstrak. Menurut Izutsu, analisis semantik akan membentuk sebuah ontologi wujud (being) dan eksistensi pada tingkat konkrit sebagaimana tercermin di dalam ayat-ayat al-Quran. Hal tersebut bertujuan memunculkan tipe ontologi hidup yang dinamis dari al-Quran dengan kajian analistis dan metodologi terhadap konsep-konsep pokok, yaitu konsep-konsep yang tampaknya memainkan peranan menentukan dalam pembentukan visi Qurani tentang alam semesta (Izutsu, 2004, hal. 1). Jadi, semantik yang digunakan oleh sarjana Jepang ini tidak hanya berusaha memahami makna tetapi sekaligus budaya yang terkandung di dalamnya. Izutsu berusaha untuk membiarkan al-Quran mentafsirkan konsepnya sendiri dan berbicara untuk dirinya sendiri (Izutsu, 2004, hal. 3), agar pemahaman terhadap alQuran tidak mengalami penyimpangan. Karena kaidah semantik bisa memahami makna yang diinginkan al-Quran secara mandiri, bukan dari penafsir. Namun, tidak dapat dihindari bahwa pengaruh penafsir dalam memahami teks akan menjadi bagian dari produk tafsirnya atau pemahamannya.

Kaidah ini dimulai dengan membuka seluruh kosa kata al-Quran, dan menghimpun kata penting yang mewakili konsep-konsep penting seperti Allah, Islam, nabi, iman, dan kafir serta menelaah maknanya dalam kontek al-Quran, bukan kontek sempit berkaitan dengan alasan turunnya ayat tertentu. Disadari atau tidak telaah 
semacam ini tidak mudah karena sulit menentukan makna dan relasi bahasa. Munculnya kesulitan disebabkan kontek yang terpisah, tetapi sangat saling bergantung untuk menghasilkan makna konkret harus menyatukan secara keseluruhan sistem tersebut. Artinya, kata-kata itu membentuk kelompok-kelompok yang beranekaragam, besar dan kecil, dan berhubungan satu sama lain dengan pelbagai cara, lalu pada akhirnya menghasilkan keteraturan yang menyeluruh, sangat rumit sebagai rangka kerja gabungan konseptual. Dengan demikian, dalam menganalisis konsep-konsep kunci dalam al-Quran, seorang penafsir tidak bisa kehilangan wawasan dari hubungan horison-horison yang saling memberi muatan dalam keseluruhan sistem.

Secara linguistik al-Quran merupakan satu karya asli berbahasa Arab. Oleh karena itu, semua kata yang digunakan dalam al-Quran memiliki hubungan dengan peradaban pra-Islam. Dengan kata lain, beberapa kata tersebut berasal dari perbendaharaan Arab pra-Islam (Izutsu, 2004, hal. 39). Namun demikian, pemaknaan terhadap kata ini mengalami penyesuaian karena medan semantik dan hubungan relasional dengan kata lain yang terdapat di dalam konsep al-Quran. Meskipun perubahan makna adalah mungkin dalam semantik karena hakikat bahasa diwariskan kepada generasi selanjutnya tidak secara berkelanjutan. Setiap generasi akan memberikan pemahaman baru. Di sini, Izutsu menggunakan bahan sejarah masyarakat Arab untuk mengokohkan tesisnya tentang tautan bahasa dan pandangan hidup sebuah bangsa.

\section{Analisis Semantik terhadap al-Quran}

Menurut Izutsu, ada banyak cara untuk memahami makna dari kata asing. Cara yang paling sederhana dan umum adalah memberikan padanan kata dalam bahasa sendiri-tetapi kaidah ini kurang dapat dihandalkan- seperti kata gatte (Jerman), mempunyai makna yang sama dengan husband (Inggris) atau suami di dalam bahasa Indonesia. Izutsu memberi contoh beberapa kata Arab yang bisa diterjemahkan ke dalam bahasa lain untuk memahami maknanya, yaitu kafir yang maknanya disamakan dengan misbeliever (orang yang tidak percaya), zalim sebagai evil-doer (orang yang aniaya), dhanb sebagai $\sin$ (dosa). 
Ada beberapa persamaan makna secara semantik dari masing-masing kata. Namun, siapapun yang mengenal karakteristik bahasa Arab akan mengakui bahwa tidak semua makna yang tampak mendekati sesuai dengan makna aslinya, seperti kata zalim secara tepat tidak dapat dipersamakan dengan evil-doer dan antara kafir dengan misbeliever terdapat perbedaan signifikan yang tidak bisa diabaikan (Izutsu, 2004, hal. 25). Oleh karena itu, terjemahan bisa menyebabkan kesalahpahaman dan bahkan menyesatkan (Izutsu, 2004). Lalu, bagaimana agar pembaca kitab suci bisa menangkap makna yang dimaksudkan, dia mengusulkan pendekatan semantik yang telah mengalami penyesuaian. Untuk memahami bagaimana semantik dimanfaatkan oleh Izutsu, ada beberapa karya yang harus menjadi rujukan, yaitu Ethico-Religious Concepts in the Quran. Supaya kajian lebih beragam karya Muhammad Naquib al-Attas dalam The Mysticism of Hamzah Fansuri dapat menjadi rujukan.

Ada empat hal penting yang perlu dipahami sebelum menerapkan semantik terhadap teks al-Quran, yaitu memahami keterpaduan konsep-konsep individual, kosa kata, makna dasar dan makna kaitan, serta pandangan dunia (weltanschauung). Keterpaduan konsep individual tampak mudah dengan membuka seluruh kata alQuran, seperti Allah, Islam, nabi, iman, kafir dan lain sebagainya. Semua kata penting yang mewakili konsep-konsep utama menurut Izutsu tidak mudah diterapkan karena konsep di dalam al-Quran rumit. Begitu juga susunan ayat al-Quran tidak disusun secara sistematik, di mana ayat yang sebelum dan sesudahnya tidak membahas satu persoalan khusus. Kedudukannya masing-masing saling terpisah, tetapi sangat saling bergantung dan justru menghasilkan makna konkret dari seluruh sistem hubungan itu (Izutsu, 2004, hal. 4).

Menurut Izutsu, pembaca terlebih dahulu memahami makna dari masingmasing konsep dalam pengertian asas (basic) dan kaitan (relational), yang pertama, begitu nyata dan kerap sangat dangkal dan biasa untuk dijelaskan, dan yang lainnya mungkin sekilas tidak begitu jelas (Izutsu, 2004, hal. 9). Sisi nyata di sini adalah bahwa masing-masing kata yang diambil secara terpisah, memiliki makna dasar atau kandungan kontekstualnya sendiri yang akan tetap melekat kepada kata. Meskipun diambil di luar konteks al-Quran. Izutsu memberikan contoh kata kitab, di mana makna dasar dari kata ini, baik yang ditemukan dalam al-Quran maupun di luar adalah sama. 
Kata ini dirasakan secara aktual oleh masyarakat penuturnya menjadi satu kata, dan tetap mempertahankan makna asasnya yaitu kitab. Penggunaan kata tersebut baik sebagai istilah kunci dalam sistem konsep yang ada atau lebih umum di luar sistem khusus tetap mempunyai makna sama. Selain itu, makna dari sebuah kata dipengaruhi oleh kata yang ada didekatnya, oleh keseluruhan sistem dimana kata itu berada (Izutsu, 2004, hal. 135-177).

\section{Hubungan Ontologi}

Persoalan manusia bersumber dari pandangan dunia keagamaan dan filsafat terkait pertanyaan abadi: dari mana manusia berasal? Apa sumber wujudnya di dunia ini? Di dalam konsepsi al-Quran jawaban yang benar adalah sumber wujud itu adalah Tuhan itu sendiri dan eksistensi itu dianugerahkan oleh Tuhan kepada manusia sebagai pemberian yang perlu disyukuri (Izutsu, 2004). Dengan jelas al-Quran menjawab bahwa antara Tuhan dan manusia mempunyai hubungan mendasar yaitu antara pencipta dan yang diciptakan, di mana Allah berperan sebagai pemberi eksistensi dan wujud kepada manusia.

Konsep penciptaan di atas adalah sebagai pesan revolusioner dan tanda bahwa Islam telah memberikan wajah baru terhadap eksistensi manusia, di mana pada masa sebelumnya, orang-orang pra-Islam tidak mengenal konsep ini, meskipun mengenal kata Allah tetapi dalam hal penciptaan biasanya dikaitkan dengan berhala-berhala. Hal ini bisa dilihat dalam penjelasan al-Quran sendiri:

"Apakah mereka menjadikan beberapa sekutu bagi Allah yang dapat menciptakan seperti ciptaan-Nya sehingga kedua-dua ciptaan itu serupa menurut pandangan mereka?" Katakanlah: "Allah adalah Pencipta segala sesuatu dan Dialah Tuhan Yang Maha Esa lagi Maha Perkasa”. (QS. ar-Ra'd: 16)

Dalam kesusastraan Jahiliah juga ditemukan tentang konsep penciptaan hubungan manusia dengan tuhan yang dekat dengan konsep al-Quran, seperti pada syair karya Antarah mengenai konsep penciptaan yang dihubungkan dengan Tuhan:

Hai burung, yang bertengger di pohon arak, demi Tuhan yang menciptakanmu, kau tentu tahu di mana mereka (yakni orang-orang yang kukasihi) kini berada. 
Menurut Izutsu, syair tersebut memperjelas peran Tuhan dalam menciptakan, meskipun digunakan dalam bentuk sumpah. Namun ada syair lain yang lebih mendekati konsep al-Quran tentang penciptaan, seperti sajak Antarah yang berbicara tentang seorang gadis yang baru saja meninggal, berikut ini:

"Ia berharap untuk hidup lama. Namun, Dia yang menciptakan semua yang telah ada telah mengambil hidupnya untuk kembali (kepada keadaan asal).

Adanya kesesuaian antara kesaksian al-Quran dan kesusastraan pra-Islam mengenai adanya konsep penciptaan, seberapa jauh kedua konsep tersebut bisa menentukan sifat weltanschauung Arab pra-Islam? Jelas jawabannya bahwa konsep eksistensi jahiliah adalah lemah dan bahkan tidak mempengaruhi kehidupan nyatanyata orang Arab jahiliah. Artinya, orang Jahiliah dapat hidup dengan nyaman tanpa perlu menumpukan perhatian sama sekali terhadap asal-usul eksistensinya sendiri. Hal ini berbeda dengan dorongan al-Quran bahwa orang muslim selalu menyadari eksistensinya sebagai makhluk (Izutsu, 2004b).

Dengan tegas Izutsu menuntaskan hubungan ontologi Tuhan dan manusia yang bersifat atas-bawah, meskipun juga mempunyai hubungan dengan tiga wilayah berbeda sehingga tidak merampas kemandirian manusia untuk berusaha berkaitan dengan nasib. Tampaknya, kesimpulan Izutsu sesuai dengan konsep tindakan dari teologi Asy'ariyah. Bagaimanapun, pada zaman jahiliah, orang-orang Arab lebih menitikberatkan pada akhir kehidupan yaitu kematian. Hal tersebut adalah satu-satunya persoalan yang muncul dalam pikiran masyarakat jahiliah, semacam meditasi filsafat. Oleh karena itu, para penyair masa itu menyukai masalah khulud (kehidupan yang abadi), sesuatu yang mustahil dicapai walaupun benar-benar disadari, sehingga dikembangkan filsafat hidup yang khas, yaitu nihilisme pesimistik (Olson, 1967, hal. 514-516). Sikap pesimis ini bersumber dari keyakinan bahwa tidak ada kehidupan setelah kematian. Tubuh manusia akan rusak dan hancur setelah ajal tiba dan rohnya terbang seperti angin beritup yang dijelaskan dalam karya 'Abid ibn al-Abras:

"Apa kami ini (bukan semacam gabungan antara tubuh dan jiwa?) tubuh, yang dengannya masuk ke bumi (pada saat kematian kami), sedangkan roh (menghilang) seperti hembusan angin." 
Sebagai tahap eksistensi penting, kematian telah mengabaikan tahap kehidupan lain seperti awal kejadian manusia, meskipun diyakini bahwa Allah adalah pencipta. Bagi orang-orang Arab pra-Islam, manusia adalah aktivitas kreatif Allah, tetapi orang Arab membatasi pada awal penciptaan dan setelah itu memutuskan ikatannya dengan Allah (Izutsu, 2004, hal. 131). Sejak itulah dikuasai oleh penguasa lain yaitu Waktu (Dahr). Pengaruh tersebut berlangsung sampai detik kematiannya. Hal ini dinyatakan di dalam QS. al-Jaatsiyah 24.

"Dan mereka berkata: "Kehidupan ini tidak lain hanyalah kehidupan di dunia saja, kita mati dan hidup dan tidak ada yang membinasakan kita selain masa"

Term Dahr pada dasarnya mempunyai padanan kata yaitu, zaman (waktu), 'asr (masa, kurun), ayyam (hari), 'aud (waktu), tetapi makna dasar dari semua kata ini adalah sama. Namun menurut Muhammad Shahrur setiap kata dalam al-Quran mempunyai makna tersendiri, meskipun dalam bentuk sinonim (Shahrur, 1990). Beberapa penyair Arab memberikan pandangannya. Al-Find az-Zimmani yang mengatakan bahwa seandainya tidak ada panah 'aud menyerang pada seluruh badan dan anggota badanku sebagai keluhan atas kerusakan karena usia tua. Tarafah meluangkan (angin dan hujan) secara sempurna mengubah aspek tempat kediaman bersama-sama dengan kerusakan karena waktu. Sebenarnya tidak ada jaminan ada penentang kekuatan perusak zaman dan hal yang sama juga diungkapkan oleh Antarah bahwa "Tidak ada jalan kehidupan tampak menggembirakan bagi kita dari yang dirusak secara sempurna oleh zaman, baik menjadi usang atau baru." Puisi yang senada dilontarkan oleh 'Abdullah Salimah bahwa "jika kunci-kunci saya menjadi abu-abu, ini adalah perubatan 'asr, dan akhir yang niscaya dari semua yang muda berambut abu-abu (uban)."

Izutsu menyimpulkan bahwa pandangan pra-Islam terhadap kehidupan manusia merupakan sesuatu yang gelap dan misteri yang mengepakkan sayap kekuasaannya terhadap proses kehidupan setiap orang sejak buaian hingga ke liang lahat. Nasib manusia berada dalam cengkeraman sang waktu yang menindas dan menjajah manusia sehingga perasaan yang muncul selalu berada dalam kesengsaraan dan penderitaan. Aspek perusak dari dahr diungkapkan dengan kata-kata khusus seperti suruf, hadatsan atau hawadith, rayb dan lain-lain yang kesemuanya mempunyai arti 
giliran keberuntungan yang tidak dapat diterka. Kekuatan perusak seperti dahr terutama menjadi wujud di akhir eksistensi manusia atau kematiannya. Menariknya, dahr kemudian berubah namanya panggilan baru, seperti maniyah (jamak dari manaya), manun, himam, dan hummah. Dalam Diwan dari suku Hudayl, dua kata yang disebutkan baru saja digunakan secara bergantian, sehingga bisa disimpulkan bahwa kedua kata ini sinonim (Izutsu, 2004b).

Menurut Izutsu, dua kata tersebut mempunyai arti kematian psikologis, karena sebagai perwujudan paling akhir dan paling merusak dari kekuatan dahr. Tetapi bukan kematian dalam pengertian biologis, melainkan nasib manusia yang ditentukan oleh dahr. Kata-kata tersebut adalah kosa kata yang mengelilingi dahr untuk menunjukkan fase akhir kekuasaan dahr. Menurut Izutsu, pemahaman tersebut disebut sebagai determinisme-Istilah yang dikenali sebagai satu sebutan untuk dua doktrin yang berbeda tetapi masih berkaitan. Pertama, pilihan antara dua tindakan yang berbeda dalam banyak kasus sepenuhnya disebabkan oleh keadaan psikologis dan sedikit memainkan peranan di dalam historiografi. Kedua berusaha menghindari ambiguitas, yang juga disebut "determinisme universal" adalah doktrin bahwa segala sesuatu yang terjadi merupakan sebuah rangkaian sebab-akibat (Donagan, 1973, hal. 18-25)-dimana orang-orang Arab pra-Islam meyakini bahwa titik akhir kehidupan manusia secara pasti telah ditentukan sebelumnya, yaitu setiap manusia mempunyai hari yang telah dijanjikan, ketika harus menghadapi kematian. Dalam sudut pandang ini kematian adalah 'ajal atau waktu yang telah dijanjikan. Tiada kekuatan yang bisa menghalangi ketika 'ajal telah tiba. Al-Salakah, ibu dari al-Salik yang diasingkan pada masa praIslam, meratapi kematian anak lelakinya dan pada waktu yang sama menghibur dirinya dengan:

"Apa saja bisa membunuhmu apabila 'ajalmu telah tiba"

Dalam puisi yang lain, al-Nabighah menyatakan bahwa dahr merupakan sesuatu yang tertulis (maktub, dari akar kata kataba "menulis") dan seorang tidak dapat menundanya sehari dan Urwah bin al-Ward menulis dalam bentuk pertanyaan:

"Ketika sampai kepadaku panah kematian (kiasan tenang suatu permainan untung-untungan, sejenis lotre dengan anak panah), maka aku tidak pernah 
kehilangan kesabaran, karena (apa gunanya?). Apakah benar-benar ada yang dapat tetapi hidup melewati (masa yang dijanjikan)?"

Ungkapan Urwah dapat dipahami bahwa pandangan orang Arab pra-Islam terhadap kehidupan sangat suram. Seluruh masa kehidupan dipahami sebagai serangkaian peristiwa yang penuh bencana, yang tidak dikawal oleh hukum pertumbuhan dan kerusakan alamiah, tetapi oleh suatu kehendak ghaib yang tidak dapat dimengerti dan gelap, sesuatu yang bersifat setengah pribadi, sehingga tidak ada jalan keluar. Latar belakang atmosfer tragis ini adalah penting untuk memahami pentingnya sejarah dari dunia al-Quran. Al-Quran menawarkan sebuah gambaran yang berbeda tentang keadaan manusia. Dengan gaya plastis, menggambarkan bahwa tibatiba langit menjadi cerah, kegelapan hilang, dan dalam suasana tragis tersebut muncul pemandangan baru tentang kehidupan abadi yang cerah. Perbedaan kedua pandangan dunia tersebut benar-benar laksana perbedaan antara siang dan malam, sesuatu yang berlolak belakang sama sekali.

Izutsu menegaskan bahwa dalam sistem Islam, Allah juga merupakan pencipta yang menandakan titik awal kehidupan manusia. Hal ini berbeda dengan konsep jahiliah yang menyatakan bahwa aktivitas kreatif Allah adalah awal maupun akhir campurtangan-Nya dalam urusan manusia dan tidak menaruh perhatian pada yang diciptakan, seperti seorang ayah tidak bertanggungjawab dan tidak pernah menaruh perhatian terhadap anak-anaknya. Parahnya, tugas tersebut diambil alih oleh wujud lain yang disebut dahr (Izutsu, 2004, hal. 137). Menurut ajaran Islam, penciptaan hanya menandakan awal kekuasaan Tuhan terhadap segala sesuatu. Semua urusan manusia, sampai yang terkecil dan tidak berarti sekalipun semuanya berada dalam pengawasan Allah. Justru, yang paling penting mengenai hal ini adalah bahwa Tuhan adalah Tuhan yang Maha Adil, yang tidak pernah berbuat salah (zulm) terhadap siapapun, bukan lagi dahr dan bukan lagi akal bulus dahr. Dengan tegas, eksistensi dahr secara terangterangan disangkal sebagai hasil imajinasi yang tidak berdasar.

Al-Quran tidak menyangkal kematian sebagai sebuah keniscayaan, sebagaimana firman Allāh di dalam beberapa tempat di dalam QS. an-Nisa 78, QS. al-Anbiya 34-35, QS. al-Waqi'ah 60 dan QS. at-Taubah 116. yang menjelaskan bahwa kematian itu telah ditetapkan dan tidak ada sesuatu pun yang dapat menghalangi. Demikian juga konsep 
'ajal tetap ada di dalam konsep Islam, namun ketentuannya berasal dari Allah, bukan yang lain. Al-Quran juga telah menyatakan dengan tegas dalam QS. an-An'am 2.

("Dialah yang menciptidakan kamu dari tanah, selepas itu ditentukannya ajal (kematianmu), dan ada lagi suatu ajal yang ditentukan (untuk berbangkit) yang ada pada sisi-Nya (yang Dia sendirilah yang mengetahuinya).”

Jika kematian dipahami sebagai akhir kehidupan manusia di dunia, maka adalah wajar pada zaman jahiliah dipahami sebagai titik akhir eksistensi manusia. Sementara di dalam Islam, kehidupan itu tidak hanya di dunia tetapi juga di akhirat sehingga kematian merupakan permulaan kehidupan yang sama sekali baru dan berbeda, kehidupan yang abadi (khulud). Ajaran Islam menegaskan bahwa kematian adalah tahap pertengahan dari seluruh rentang kehidupan manusia, suatu titik balik dalam sejarah kehidupan manusia di antara dunia dan akhirat. Sebuah perbedaan tajam di antara pandangan dunia kedua-dua kelompok masyarakat ini. Selain itu, ajal juga dimiliki oleh dunia, tidak hanya manusia. Dalam semua proses ini, Islam menegaskan bahwa seluruhnya berada dalam kekuasaan mutlak Allah. Kekuasaan mutlak Tuhan adalah sebagai perwujudan dari pesan utama kitab suci tentang aspek ontologis dalam Islam. Secara tersirat, ini menunjukkan bahwa tidak ada kuasa yang bisa melebihi Allah. Selain itu, segala sesuatu di dunia nyata ini akan kembali kepada pemilik sejati. Dengan tegas bisa dikatakan bahwa kosmologi Islam berpusat pada Tuhan sang pencipta.

\section{Hubungan Komunikatif Manusia dengan Tuhan}

Ada dua tipe dalam memahami hubungan manusia dengan Tuhan, yaitu bersifat linguistik atau kata-kata dan bukan kata-kata (non-verbal). Yang terakhir ini biasanya melalui tanda-tanda alam, isyarat dan gerakan tubuh manusia. Dalam dua kasus ini, inisiatif pada umumnya diambil oleh Tuhan sendiri, sedangkan manusia pada dasarnya menanggapi inisiatif ini (Izutsu, 2004b). Dalam melakukan komunikasi dengan manusia, Tuhan mengirimkan ayat (bentuk jamak dari ayah) melalui wahyu yang menggunakan bahasa. Ayat tersebut pada dasarnya tidak membedakan antara tandatanda linguistik maupun bukan. Oleh karena itu, untuk memahami kata ayat perlu dilacak asal-usulnya. Menurut Izutsu, kata ini sebenarnya telah digunakan pada masa pra-Islam, meskipun tidak pernah dipakai di dalam pengertian keagamaan. Tetapi, bagi 
kalangan kaum hanif, kata ayat mempunyai nuansa yang berbeda sebagaimana bisa dilihat dalam syair Labid sebagai berikut:

"Dan air dan abi (dengan kata lain huian. cahava langit sederti matahari. bulan dan bintang-bintang) adalah avat-Nva. Di dalamnva terdabat Delaiaran untuk orang-orang yang tidak jahil (yakni, orang-orang yang bisa berpikir dengan benar).”

Persoalan yang terpenting adalah struktur semantik dari kata ayat dalam alQuran. Ayat ilahi yang dapat dipahami dari al-Quran dalam pengertian umum ialah meliputi simbol-simbol verbal maupun bukan-verbal. Jenis verbal, yaitu wahyu, dalam kasus ini lebih jelas karena pada dasarnya bersifat konseptual. Wahyu menjelaskan kehendak Tuhan dalam bentuk yang jelas. Dengan kata lain, Izutsu menyatakan bahwa apa yang ingin disampaikan Tuhan kepada manusia diberikan secara analitik, satu unsur mengikuti unsur yang lainnya, setiap unsur diajukan secara konseptual. Sementara pada tipe bukan verbal, kehendak Tuhan diwujudkan secara umum, bukan secara analitik. Meskipun, pesan bukan-verbal tidak bersifat konseptual tetapi ayat bukan verbal memiliki kelebihan, karena dapat ditujukan pada umat manusia secara keseluruhan tanpa diskriminasi; dan dapat diberikan langsung tanpa perantara, ketika tipe verbal hanya bisa diberikan kepada umat manusia. Pendek kata, semua manusia hidup di tengah-tengah dunia simbol ilahiah, dan simbol ini dapat dicapai oleh sesiapa saja apabila memiliki kemampuan mental dan spiritual untuk menafsirkan sebagai simbol-simbol (Izutsu, 2004, hal. 145). Namun kedua bentuk komunikasi ini tidak bisa dipisahkan karena satu sama lain saling mendukung untuk menemukan makna sejati dari pesan Allah kepada manusia.

Sebuah prosedur pemahaman semantik mengandaikan bahwa kata ayat mempunyai korelasi dengan kata kunci lain yang membentuk kesatuan pengertian, atau apa yang disebut dengan medan semantik. Menurut Izutsu, hal yang terpenting berkenaan dengan ayat Ilahi, baik verbal dan bukan verbal, adalah respons yang dapat diberikan manusia terhadapnya, baik menerima maupun menolak atau tasdiq dan takdzib. Manusia yang menerima ayat sebagai kebenaran (haqq) dan menolaknya langsung sebagai kepalsuan (batil) yang tidak memiliki realitas dan hanya sebagai hasil fantasi dan imajinasi yang tidak logis. Selanjutnya, bisa dilihat gambar 5 untuk melihat tangapan manusia dalam memahami ayat Tuhan bukan linguistik. 


\section{Hubungan Tuan-Hamba}

Hubungan ini adalah hirarki antara Pencipta dan Makhluk. Tuhan sebagai "Tuan" ( $r a b b)$ dan manusia sebagai hamba ('abd). Pengertian semacam ini sebenarnya telah dikenal di dalam tradisi Arab jahiliah. Namun, pada masa itu Allah bukan merupakan satu-satunya Tuhan dan bersifat mutlak. Ada beberapa rabb dan rabbah lain di samping Allah. Kedatangan Islam merubah paradigma politeisme menjadi monoteisme yaitu, Allah sebagai Penguasa mutlak, satu-satunya Tuhan yang berkuasa mutlak di seluruh dunia (Izutsu, 2004b). Pengakuan terhadap kemutlakan ini menandakan bahwa bukan saja manusia biasa, tetapi juga nabi-nabi dan bahkan malaikat pun tidak bisa dianggap sebagai Tuhan (arbab) dalam pengertian apapun. Sebagaimana firman Allah dalam QS. al 'Imran 80 yang menyatidakan bahwa bahkan para malaikat berada di sisi Allah (al-malaikah al-muqarrabun) pun tidak diizinkan untuk menganggap lebih rendah terhadap hamba-hamba-Nya yang beriman dan berserah diri.

Peralihan dari kepercayaan politeisme ke monoteisme menyebabkan perubahan radikal terhadap konsepsi hubungan antara Tuhan dan manusia. Sebuah medan semantik baru terbentuk di sekitar ide baru ini yang bisa dilihat dari kata-kata kunci penting di dalam al-Quran, seperti ta'at (patuh) QS. al-Ma'idah 92, qunut (setia, berserah diri), QS. al-Baqarah 110 khushu' (penyerahan) QS. al-Hadid 16, dan tadarruc (menghinakan diri) QS. al-An’am 42. Menurut Izutsu, semua konsep yang masuk ke dalam kelompok ini adalah konsep Islam, tentu saja bukan dalam arti historis atau kebudayaan keagamaan objektif yang dikenal sebagai Islam sebagaimana dikatakan disebut sebagai proses refikasi Islam - dipinjam dari Wilfred Cantwell Smith, tetapi Islam menurut makna yang sesungguhnya, yaitu berserah diri, menyerahkan diri kepada kehendak Ilahi. Kutipan dari pendapat Izutsu berikut ini menegaskan lebih jauh tentang pengertian Islam:

Like most of the Quranic key-terms, Islam, or at least its verbal form aslama, has its pre-Islamic history. In Jahiliyyah the word meant "giving over" in general. To be more precise, aslama means that a man gives over something which is difficult or painful for himto abandon, to somebody who demands it. This precious something may be his own self, which is of course, in most cases, the most precious possesion a man has in in hand; (in which case it means 
naturally total submission, self-surrendering); it may also be somebody else, one of his dear friendsor his tribesmen (in which case it would mean betrayal). In any case the basic meaning is that of giving over one's precious possession to somebody else (Izutsu, 2004, hal. 251).

Dari makna dasar ini, Islam (kata kerjanya adalah aslama) berdasarkan pengertian yang digunakan di dalam frasa aslama wajhahu lillah yang secara harfiah berarti "telah menyerahkan wajahnya kepada Allah", makna sesungguhnya adalah seseorang yang dengan sukarela menyerahkan dirinya kepada kehendak Allah dan memercayakan dirinya sepenuhnya kepada Allah. Secara singkat, hal tersebut merupakan bentuk penyerahan diri tanpa syarat yang secara verbal diungkapkan di dalam ayat berikut ini:

"Ya Tuhan kami, jadikanlah kami berdua orang yang tunduk patuh kepada Engkau!" (QS. al-Baqarah 128)

Selain kepentingan makna dari kata Islam, konsep ini menjadi sangat kokoh kedudukannya karena telah dipilih sebagai nama agama baru di tanah Arab dan faktanya adalah sebagai pengalaman batin keagamaan yang bersifat pribadi pada tiaptiap orang, merupakan peristiwa penting yang menandakan titik awal dari penyerahan dan kerendahan diri yang sesungguhnya. Bahkan, menandakan titik balik yang menentukan pada kehidupan seseorang, suatu titik balik dalam kesadaran keagamaan yang memotong seluruh rentang kehidupan menjadi dua bagian (A, B) yang secara diametrik bertentangan satu sama lain.

Kata aslama adalah kata kerja yang dimasukkan ke dalam kelompok kata kerja inchoative. Artinya, ia menunjukkan sesuatu yang baru yang wujud untuk pertama kalinya; yang menandai awal dari situasi baru. Hanya saja dalam bentuk partisipal, muslim menunjukkan sifat yang kurang lebih tetap. Bahkan kemudian ia adalah sebuah sifat yang muncul dari sebuah langkah pasti. Sementara istilah al-Quran lainnya yang bermakna kepatuhan dan penyerahan sangat samar-samar dan tidak semakna. Dalam struktur semantik tidak ditemukan peristiwa keputusan eksistensial, peristiwa lompatan ke dalam bidang kehidupan yang tidak diketahui. Hanya kata Islam yang mempunyai implikasi seperti itu. Seorang muslim, menurut Izutsu (1997) pengertian asalnya adalah orang yang memiliki keberanian semacam itu yaitu ketika kata ini digunakan pada awal 
periode Islam sebagaimana digambarkan dalam al-Quran, pada waktu semua orang Islam tanpa kecuali, termasuk Nabi sendiri pernah hidup dalam suasana pagan. Lalu, setelah kata ini dikaitkan dengan konsep tertinggi dalam Islam, Allah, maka konsep seperti kepatuhan, penyerahan, dan kerendahan mulai muncul dan mengandung makna keagamaan yang sesungguhnya.

\section{Hubungan Etika}

Dalam Islam klasik, khuluq, kata lain dari etik biasanya didefinisikan sebagai keadaan jiwa yang menentukan tindakan manusia (Manzur, n.d., hal. 1244-1248). Sementara subjek utama dari akhlak adalah apa yang baik bagi manusia, dengan kata lain keutamaan dan kebahagiaan jiwa, tiga kemampuan jiwa dan pengaruhnya pada watidak dan akhirnya adalah teori pengawalan diri atau perbaikan watidak melalui pengetahuan, disiplin dan hubungannya dengan orang lain sehingga jiwa bebas dari maksiat, dan mencapai kesempurnaan dan kebahagiaan yang utuh (Omar, 2003).

Menurut Izustu, terdapat tiga kategori yang berbeda mengenai konsep-konsep etik di dalam al-Quran. Pertama, kategori yang menunjukkan dan menguraikan sifat Tuhan. Kedua, kategori yang menjelaskan pelbagai macam aspek sifat fundamental manusia terhadap Tuhan dan ketiga adalah kategori yang menunjukkan tentang prinsip-prinsip dan aturan-aturan tingkah laku yang menjadi milik dan hidup di dalam masyarakat Islam (Izutsu, 2004a).

Kelompok pertama terdiri dari apa yang disebut dengan nama-nama Tuhan (alasma al-husna), seperti pemurah, penuh kebaikan, adil, atau penuh keagungan, yang menguraikan sifat khas yang hanya dimiliki Tuhan yang digambarkan oleh al-Quran. Semua sifat ini pada hakikatnya bersifat etik. Demikian pula etika manusia dapat dimasukkan ke dalam etika ketuhanan, artinya Tuhan bersifat etik dan tindakannya terhadap manusia dengan cara yang etik membawa kepada pengertian yang sangat penting bahwa manusia diharapkan untuk merespons dengan cara yang etik pula. Dengan demikian, karena al-Quran itu adalah agama itu sendiri, secara otomatis mengandung etika dan agama sekaligus (Izutsu, 2004a). Dengan mengatakan seseorang harus bersikap seperti itu terhadap Tuhan dalam merespon sikap-Nya terhadap umat manusia, dan manusia harus bertindak dengan cara sedemikian rupa berdasarkan 
perintah Tuhan dan larangan-Nya, kedua-dua bentuk ini adalah ajaran etik dan agama. Dengan demikian, semua konsep yang dimiliki kedua kelompok di atas dapat diuraikan sebagai konsep etika keagamaan.

Implikasi terhadap sikap etika manusia terhadap Tuhan terwujud dalam etika antara sesama manusia yang hidup dalam masyarakat yang sama. Kehidupan sosial seseorang diatur oleh seperangkat prinsip moral beserta semua kata turunannya. Akhirnya, aturan-aturan ini membentuk apa yang disebut dengan sistem etika sosial, yang selanjutnya dalam periode pasca al-Quran dikembangkan menjadi sistem hukum Islam berskala besar. Namun, yang terakhir ini di luar kajian Izutsu, meskipun kadang dijadikan acuan dalam usaha untuk membedakan antara prinsip-prinsip etik dalam alQuran dan jahiliah.

Perlu dipahami bahwa ketiga kelompok etika di atas tidak berdiri sendiri, tetapi memiliki hubungan sangat erat. Hal ini disebabkan oleh sebuah premis bahwa pandangan dunia al-Quran pada hakikatnya bersifat teosentrik. Gambaran tentang Tuhan meliputi seluruh gambaran tersebut dan tidak ada yang terlepas dari ilmu-Nya dan pengawasan-Nya. Secara semantik, jelas Izutsu, hal ini berarti pada umumnya, tidak ada konsep utama dalam al-Quran yang terlepas dari konsep tentang Tuhan dan di bidang etika manusia masing-masing konsep tidak lain adalah sebagai refleksi semu atau satu tiruan yang sangat tidak sempurna dari sifat Tuhan itu sendiri, atau mengacu pada suatu respons khusus yang berasal dari perbuatan Tuhan.

Etika berkaitan dengan apa yang harus dilakukan oleh manusia terhadap Tuhan berkaitan dengan perintah dan larangan dan bagaimana Tuhan berkehendak terhadap Makhluk-Nya (Izutsu, 2004a). Al-Quran dengan jelas menunjukkan dua aspek yang berbeda yang secara asas saling bertentangan. Bagi pikiran yang rendah hati dan beriman, dua aspek ini tidak lain merupakan dua sisi dari satu Tuhan yang sama, tetapi bagi logika minda awam, kedua-dua sisi ini tampak bertentangan. Aspek yang pertama adalah Allāh memperlihatkan diri-Nya sebagai Tuhan yang maha pemurah, Tuhan Maha pengasih, penyayang dan maha pengampun. Semua aspek ini disebutkan dalam al-Quran dengan kata kunci seperti ni'mah (kenikmatan), fadl (kemurahan hati), rahmah (kasih sayang), dan maghfirah (ampunan) (Izutsu, 2004b). 
Lalu bagaimana tindakan manusia terhadap semua karunia dan kebaikan ini? Satu-satunya kemungkinan respons yang benar terhadap ayat (tanda-tanda) ini adalah rasa terima kasih atau syukur. Namun demikian, tanggapan ini hanya dapat dimengerti berdasarkan pemahaman dan pandangan yang benar terhadap ayat ilahi. Artinya, rasa terima kasih hanya mungkin terwujud apabila manusia sudah mengerti makna ayat tersebut. Untuk memahami lebih jauh kata syukur juga bisa dipahami dari lawan kata ini, yaitu kufr, yang makna tepatnya adalah tidak berterima kasih. Sebenarnya struktur konseptualnya sendiri sudah berakar kuat pada masa jahiliah. Pada kurun itu, seseorang yang memberikan sesuatu pada orang lain, reaksi wajar yang ditunjukkan oleh penerima adalah seharusnya berterima kasih. Hakikatnya, ini adalah aturan paling dasar yang mengatur hubungan-etik antara manusia. Namun, sayangnya al-Quran menyatidakan sebaliknya:

"Sesungguhnya manusia itu sangat tidak bersyukur kepada Tuhannya!" (QS. al-'Adiyat 6)

"Sesungguhnya manusia itu benar-benar pengingkar yang nyata (terhadap rahmat Allah).” (QS. al-Zukhruf 15)

Menurut Izutsu rasa tidak bersyukur itu bersifat keagamaan atau tidak adalah tanggapan manusia terhadap kebaikan yang diperlihatkan kepada orang lain. Struktur kata ini tetap sama tanpa menghiraukan apakah kenikmatan (ni'mah) yang telah dianugerahkan kepadanya bersifat sekuler atau keagamaan. Sikap sekuler bisa dilihat pada pandangan hidup orang Arab yang memperlihatkan bahwa kehidupan disesuaikan dengan perintah aturan moral tertinggi yaitu mensyukuri nikmat. Sebagaimana syair dari suku Hudayl (Izutsu, 2004, hal. 256):

"Bila kamu berterima kasih kepadaku (seharusnya memang demikian) maka kamu menunjukkan rasa terima kasih akan (nikmat) yang telah aku anugerahkan kepadamu, tetapi apabila engkau ingkar (kufr) kepadaku, aku tidak akan memaksa supaya kamu berterima kasih kepadaku"

Al-Quran tidak memberikan pemaknaan baru terhadap kata, namun demikian ia mengangkatnya ke dalam tingkatan keagamaan. Struktur konseptual masih tetap sama, tetapi kemudian ditempatkan pada tingkatan batiniah yang lebih tinggi sebagai hubungan antara Tuhan dan manusia, sehingga ni'mah di sini merupakan karunia Allah 
dimana manusia menanggapinya secara benar, yaitu dengan syukr atau dengan cara keliru, yaitu kufr. Jadi, kafir tidak lagi hanya dipahami sebagai bukan Islam dan dilabelkan kepada orang-orang selain Islam. Pendek kata, istilah ini bisa jadi disematkan kepada orang Islam yang tidak pandai bersyukur. Dengan demikian, penggunaan kata kafir yang dimanfaatkan oleh ramai orang untuk menyebut orang selain Islam tidak sepenuhnya bisa dipertanggungjawabkan. Seharusnya ditegaskan bahwa kata ini bisa saja dilabelkan kepada muslim itu sendiri.

\section{Simpulan}

Sejauh mungkin, penulis mencoba untuk menampilkan pemikiran sarjana termasyhur Jepang ini apa adanya, tanpa memberikan tafsiran apa pun, kecuali pada penjelasan konseptual dari istilah-istilah yang digunakan beliau. Penggunaan istilah teknis dari istilah-istilah yang diterangkan maksudnya, saya berusaha untuk memberikan penjelasan agar membantu pembaca di dalam memahami pemikiran Izutsu, seperti weltanschauung, gestalt, nihilisme pesimistik, dan lain-lain. Pemilihan analisis semantik oleh Izutsu telah disadari sejak permulaan sebagai salah satu pendekatan dalam memahami kitab suci al-Quran, di samping kaidah lain yang bisa digunakan untuk mengerti kandungannya, seperti teologi, filsafat, sosiologi, nahwu dan takwil (exegesis). Secara tersurat kita bisa mengambil kesimpulan bahwa ilmu tafsir adalah salah satu cara untuk menerokai pesan al-Quran. Ia bukan satu-satunya kaidah yang berwibawa untuk menafsirkan kitab suci. Tentu saja, kesimpulan ini akan banyak mengganggu sarjana muslim yang menganggap cara di luar tradisi tafsir tidak sah.

Melalui kaidah linguistik, tepatnya semantik, dan didukung oleh disiplin filsafat yang beliau kuasai dengan baik, sarjana Jepang ini berkeyakinan bahwa kitab suci alQuran itu berasal dari Allah, bukan buatan Muhammad. Meskipun, ia berupa ayat yang bisa dipahami oleh manusia, namun hakikatnya, pemahaman Nabi Muhammad diperolehi melalui naiknya eksistensi dia sejajar dengan eksistensi Allah. Dengan demikian, adalah tidak mustahil jika Nabi Muhammad mampu menangkap kehendak Allah. Berdasarkan keyakinan inilah, Izutsu memulai sebuah kajian yang langsung menggunakan teks al-Quran itu sendiri untuk mendapatkan pesanan, yaitu memahami 
al-Quran dengan al-Quran itu sendiri. Kaidah ini menurut sebagian ulama tradisional sebagai pendekatan yang paling utama dan menurut ahli linguistik dikenal sebagai pemahaman terhadap munasabah satu teks dengan teks yang lain (intertekstualitas).

Dalam memahami tema hubungan Tuhan dan manusia, dia akhirnya berkesimpulan bahwa hubungan antara kedua-duanya bisa dibagi ke dalam empat hubungan, yaitu ontologi, komunikasi, tuan-hamba dan etik. Di antara keempat tipe hubungan ini saling berhubungan dan tidak bisa dipahami secara sepotong-sepotong. Namun, secara ringkas dapat dikatakan bahwa hubungan Tuhan dan manusia mengandaikan hubungan dimana manusia menjadikan Tuhan sebagai tujuan tertinggi manusia. Manusia yang telah mencapai tingkatan ini dalam mistisisme disebut insan kamil (manusia yang sempurna). Izutsu mengandaikan adanya hubungan segi tiga antara Tuhan, manusia dan alam. Secara analogis, bisa disimpulkan bahwa alam dan manusia adalah makhluk yang mengandaikan hubungan yang sejajar dalam mengabdi kepada Allah. Oleh karena itu, alam dan manusia sama-sama tunduk kepada perintah Allah dengan cara yang berbeda. Manusia dengan mengikuti apa yang telah diperintahkan di dalam kitab suci, demikian pula alam berjalan sesuai dengan hukumhukum Allah (sunnatullah). 


\section{Referensi}

Anwar, S. (1998). Metodologi Penelitian. Yogyakarta: Pustaka Pelajar.

Donagan, A. (1973). "Determinism in History" dictionary of History of Ideas. (P. P. Wiener, Ed.). New York: Charles Scribner's Sons.

Esak, F. (1997). Qur'an Liberation and Pluralism an Islamic Perspective of Interreligious Solidarity against Oppression. Oxford: Oneworld Publications.

Izutsu, T. (1997). Relasi Tuhan dan Manusia Pendekatan Semantik terhadap al Qur'an. ( terj. A. F. Husein, Ed.). Yogyakarta: Tiara Wacana.

Izutsu, T. (2004a). Ethico-Religious Concepts in teh Qur'an. Kuala Lumpur: Islamic Book Trust.

Izutsu, T. (2004b). God and Man in the Qur'an: Semantic of teh Qur'an Wltanschauung. Kuala Lumpur: Islamic Book Trust.

Jaspers, K. (1970). Philosophy. (Ashton, Ed.). Chicago: The University of Chicago Press.

Mannheim, K. (1936). Ideology and Utopia: an Introduction to the Sosiology of Knowledge. (L. Wirth \& E. Shils, Ed.). New York: A Harvest Book.

Manzur, I. (n.d.). Lisan al Arab. Kairo: Dar al Ma’arif.

Moleong, L. J. (1989). Metodologi Penelitan Kualitatif. Bandung: Remaja Rosda Karya.

Olson, R. G. (1967). "Nihilism" The encyclopedia of Philosophy. (P. Edwards, Ed.). New York: The MacMillan Company.

Omar, M. N. (2003). Christian and Muslim Ethics: A Study of How to Attain happiness as Reflected in teh Works on Tahdhib al Akhlaq by Yahya ibn 'Adi. Kuala Lumpur: Dewan Bahasa dan Pustaka.

Shahrur, M. (1990). al-Kitab wa al-Qur'ān: Qirā'ah Mu'āsirah. Damaskus: al Ahali.

Sugiyono. (2005). Memahami Penelitian Kualitatif. Bandung: Alfath Offset.

Ullman, S. (1972). Semantics: An Introduction to the Science of Meaning. Oxford: Basil Blackwell. 